\title{
FEATURES OF THE PERFORMANCE OF NOTARIAL ACTS IN INTERNATIONAL CIRCULATION
}

\author{
Intizor Turdimatovna Mamazhonova
}

PhD Student Department of "History" Faculty of Humanities Chirchik State Pedagogical Institute

\section{ABSTRACT}

Among the law enforcement agencies of our country, the state notary is of great importance. Notarial actions effectively ensure the protection and protection of indisputable rights and interests in the event that these actions are performed in accordance with the rules established in advance by law. Documents drawn up abroad with the participation of officials of the competent authorities of other states or outgoing from them are accepted by a notary, subject to their legalization by the body of the Ministry of Foreign Affairs of the Republic of Uzbekistan. Without legalization, such documents are accepted by the notary in cases where it is provided for by the legislation and international treaties of the Republic of Uzbekistan.

KEYWORDS:- Notary, notarial act, international treaty, conflict of laws, foreign states, attestation inscription, foreign citizens, notary competence, legal assistance, consular conventions, consular legalization

\section{INTRODUCTION}

The legal status of foreign citizens when performing notarial acts is determined both by the legislation of the republic and by international treaties concluded by the Republic of Uzbekistan.

In this regard, when a notary performs a notarial act affecting the interests of foreign citizens or organizations, he must first of all find out whether the RUZ with the corresponding foreign state has an international treaty that has entered into legal force, containing a provision concerning the activities of the notary.

In the presence of such an agreement, the notary, having familiarized himself with its text and having established that it contains other rules on the performance of notarial acts than those contained in the legislation of the RUZ, applies the rules of this agreement.

According to Art. 93 "Law on Notaries", if an international treaty of the Republic of Uzbekistan assigns to the competence of a notary the performance of a notary act that is not provided for by the legislation of the Republic of Uzbekistan, the notary performs this notarial act in the manner established by the Ministry of Justice of the Republic of Uzbekistan.

\section{Material AND METhods}

International treaties containing norms concerning notarial acts are of two types: bilateral treaties on the provision of legal 
CURRENT RESEARCH JOURNAL OF HISTORY 2(5): 09-13, May 2021

DOI: https://doi.org/10.37547/history-crjh-02-05-03

ISSN 2767-472X

(C)2021 Master Journals

\section{Crossref dof 80 Google}

Accepted 15th May, 2021 \& Published 20 th May, 2021

assistance in civil, family and criminal matters, consular conventions.

It should be emphasized that at present, international legislation and bilateral treaties on the provision of legal assistance in civil, family and criminal cases are in force between Uzbekistan and other republics. For example: Convention on Legal Assistance and Legal Relations in Civil, Family and Criminal Cases Minsk, January 22, 1993. Ratified by the Resolution of the Supreme Council of the Republic of Uzbekistan dated 06.05.199 \# 825XII. Entry into force for the Republic of Uzbekistan from 19.05.1994. The Consular Convention between the Russian Federation and the Republic of Uzbekistan, ratified by the Resolution of the Supreme Council of the Republic of Uzbekistan dated 06.05.1994 No. 1076-XII, entered into force on 19.10.1995. Consular Convention between the Republic of Uzbekistan and the Republic of Poland, ratified by the Resolution of the Supreme Council of the Republic of Uzbekistan. From 06.12.1995 \# 78-I.

Agreement between the Republic of Uzbekistan and the Republic of Latvia on legal assistance and legal relations in civil, family, labor and criminal cases. Ratified by the Resolution of the Supreme Council of the Republic of Uzbekistan dated December 27, 1996 No. 358-I. Agreement between the Republic of Uzbekistan and Georgia on legal assistance and legal relations in civil, family and criminal cases. Ratified by the Resolution of the Supreme Council of the Republic of Uzbekistan dated 30.08.1996 \# 289-I. Agreement between the Republic of Uzbekistan and the Republic of Kazakhstan on legal assistance and legal relations in civil, family and criminal cases. Ratified in accordance with the Resolution of the Supreme Council of the Republic of Uzbekistan dated 30.08.1997 No. 487-I. Agreement between the Republic of Uzbekistan and the Republic of Lithuania on legal assistance and legal relations in civil, family and criminal cases, Agreement between the Republic of Uzbekistan and the Republic of Azerbaijan on legal assistance and legal relations in civil, family and criminal cases[2].

In international treaties, as well as in the legislation of the Republic, there are conflict-oflaws rules that indicate the law of which state a notary should apply when performing a specific notarial act. Usually conflict rules relate to relations in the field of inheritance. For example, an inheritance relationship is determined by the law of the country where the testator had his last permanent residence. However, the inheritance of buildings and other immovable property located in the RUZ, as well as the rights to this property, is determined by the legislation of the Republic of Uzbekistan.

The norms of international treaties governing the procedure for providing each other with legal assistance by the bodies of the contracting parties are essential for practice. Such rules are contained in agreements on the provision of legal assistance, which stipulate that in the provision of legal assistance, the institutions of justice of the contracting parties communicate with each other through their central authorities.

In the absence of an agreement on legal assistance, the appeal of the institution of justice is sent by the Ministry of Justice of the Republic of Uzbekistan by diplomatic means through the Ministry of Foreign Affairs of the RUZ.

The notary accepts documents drawn up in accordance with the requirements of international treaties, and also makes certification notices in the form provided for by the legislation of other states, if this does not contradict the international treaties of the Republic of Uzbekistan.

Notarization of documents drawn up taking into account foreign law is necessary if the documents are intended to be sent abroad. Then 
CURRENT RESEARCH JOURNAL OF HISTORY 2(5): 09-13, May 2021

DOI: https://doi.org/10.37547/history-crjh-02-05-03

ISSN 2767-472X

(C)2021 Master Journals

\section{Crossref dof 80 Google}

Accepted 15th May, 2021 \& Published 20 th May, 2021

the notary is faced with the task of familiarizing himself with the norms of foreign civil, family law and making an attestation inscription in the form provided for by foreign law. The notary can obtain information on the content of foreign legal norms from the person who applied for the notarial action, or from the Ministry of Justice of the Republic of Uzbekistan by sending a corresponding request.

\section{RESULTS AND DISCUSSION}

As for the certification inscriptions, then most often we are talking about certifying a power of attorney or the authenticity of a citizen's signature. The Ministry of Justice has approved some forms of attestation marks that are used by notaries when processing documents intended for use abroad.

The difference between such a certification inscription from the certification inscription used in the internal legal circulation consists primarily in its content. For example, an attestation inscription on a power of attorney may indicate that the principal has personally come to the notary, is known to him as the person indicated in the power of attorney, personally signed the power of attorney in the presence of the notary, duly confirmed to him that he is issuing this power of attorney. As a rule, powers of attorney intended for action abroad do not have an indication of the duration of their validity and remain in force until they are canceled by the principal.

The peculiarity of documents intended for sending abroad is also that, as a rule, the content of the document is presented in two languages with a parallel arrangement of the text. In this case, the certification inscription is placed under both texts. The certification inscription is stated in the Uzbek language. Along with the certification or certification of the document, it indicates the certification of the fidelity of the translation made by the notary or the certification of the authenticity of the signature of the translator known to the notary.

Depending on the rules adopted in a particular country, if the text of a document is presented on one sheet with a parallel translation, the document is signed separately under the Uzbek text with the letters of the Uzbek alphabet, under the foreign text - with the letters of the Latin alphabet. In these cases, two certification inscriptions are made: one - in the Uzbek language under the Uzbek text, the second - a similar inscription in a foreign language under the foreign text. A notary signs twice with the letters of the Uzbek alphabet under the Uzbek text of the certification inscription and with the letters of the Latin alphabet under the foreign text, whether the text of the translation of a document intended for action abroad is set out separately from the text of the document, then the entire text of the document, including the text certification inscription. Under the text of the translation, a certification inscription is made in the Uzbek language about the certification of the authenticity of the signature of a translator known to the notary. The translation, made separately, is attached to the document, laced up and sealed with a notary's signature and seal.

Attention should be paid to the special procedure for signing the document. On the application, power of attorney, other document, the citizen is obliged to write his last name, first name, patronymic in the sequence as indicated in the text of the document, and then sign. 
CURRENT RESEARCH JOURNAL OF HISTORY 2(5): 09-13, May 2021

DOI: https://doi.org/10.37547/history-crjh-02-05-03

ISSN 2767-472X

(C)2021 Master Journals

Crossref doi 81 Google

Accepted 15 $5^{\text {th }}$ May, 2021 \& Published 20 th May, 2021

\section{Conclusion}

When filling in the certification inscriptions, it is necessary to fully indicate the last name, first name, patronymic of the notary; the date of execution of the document shall be indicated in words if it is absent in the text of the document or indicated in numbers. The surname, name, patronymic of the person who signed the document must be indicated on the passport in the same sequence as they are indicated in the document being drawn up. The seal is affixed in an empty space, without affecting the text of the certification inscription and the signature of the notary. When drawing up documents intended for action abroad, a notary must explain to interested parties the need for their subsequent legalization. To do this, the interested person must submit a document to the notary department of the Ministry of Justice of the Republic of Uzbekistan to certify the authenticity of the signature of the notary who issued the document, and then for legalization to the consular service of the Ministry of Foreign Affairs of the Republic of Uzbekistan.

Consular legalization consists in establishing and certifying the authenticity of signatures of foreign officials on documents to confirm their compliance with the laws of a foreign state.

If an international treaty of the Republic of Uzbekistan establishes other rules on notarial actions than those provided by the legislative acts of the Republic of Uzbekistan, the rules of the international treaty are applied when performing notarial actions.

\section{REFERENCES}

1. Law on the Notary of the Republic of
Uzbekistan.-Toshkent: Adolat, 1997.

2. Convention on Legal Assistance and Legal Relations in Civil, Family and Criminal Matters. Minsk, January 22, 1993

3. Entry into force from May 19, 1994 in accordance with Article 83. Ratified by the Resolution of the Supreme Council of the Republic of Uzbekistan dated May 6, 1993 No. 825-XII

4. Resolution of the Oliy Majlis of the Republic of Uzbekistan dated 06.05.1994. No. 1076X11 // Consular Convention between the Russian Federation and the Republic of Uzbekistan.

5. Resolution of the Oliy Majlis of the Republic of Uzbekistan dated 06.12.1995..№78-1. // Consular convention between the Republic of Uzbekistan and the Republic of Poland.

6. Resolution of the Oliy Majlis of the Republic of Uzbekistan dated 27.12.1996 .. No. 3581.// Agreement between the Republic of Uzbekistan and the Republic of Latvia on legal assistance and legal relations in civil, family, labor and criminal cases.

7. Resolution of the Oliy Majlis of the Republic of Uzbekistan dated 08.30.1996..No. 289-1 // Agreement between the Republic of Uzbekistan and Georgia on legal assistance and legal relations in civil, family and criminal cases.

8. Resolution of the Oliy Majlis of the RUZ dated 30.08.1997. No. 487-1.// Agreement between the Republic of Uzbekistan and the Republic of Kazakhstan on legal assistance and legal relations in civil, family and criminal cases.

9. Resolution of the Oliy Majlis of the Republic of Uzbekistan dated 25.04.1997. No. 431-1.// Agreement between the Republic of Uzbekistan and the Republic of Lithuania on 
CURRENT RESEARCH JOURNAL OF HISTORY 2(5): 09-13, May 2021

DOI: https://doi.org/10.37547/history-crjh-02-05-03

ISSN 2767-472X

(C)2021 Master Journals

Crossref doi 8 Google

Accepted 15th May, 2021 \& Published 20 ${ }^{\text {th }}$ May, 2021

legal assistance and legal relations in civil, family and criminal cases.

10. Resolution of the Oliy Majlis of the Republic of Uzbekistan dated 30.07.1997...No 488-1 //

Agreement between the Republic of Uzbekistan and the Republic of Azerbaijan on legal assistance and legal relations in civil, family and criminal cases. 